\title{
A SENSITIVITY ANALYSIS OF RURAL COMMUTING PATTERNS: AN OCCUPATIONAL COMPARISON
}

\author{
Colette M. Hoffman and Roger J. Beck*
}

\begin{abstract}
Introduction
The purpose of this study is to present a procedure for estimating the responsiveness of potential women labor force participants to actual job holding at alternative locations. The procedure incorporates a work trip distribution technique and a variation of the gravity model in developing a weighted measure of alternative job opportunities across space. This measure, termed geographic access to employment opportunities, is used as an independent variable in estimating actual participation in the labor market for two occupational categories for women residing in Burlington County, New Jersey.
\end{abstract}

\section{Rationale}

There are several, not totally unrelated reasons for undertaking this type of study. The first is to develop a better understanding of labor force behavior within rural and surrounding communities. As Brown (1981) suggests, "spatial distribution of population and economic activities is an issue of increasing national concern." Brown (1981), Beale (1976), Wardwell and Brown (1980), and others have documented the well known reversal of rural/ urban migration; these events suggest a need to develop effective models explaining the relationship between the location of economic activity and the available labor force in rural communities.

Petrulis (1983), in analyzing firm location decisions, hypothesized that firm location decisions are influenced by the economic attributes of the communities at alternative locations. To capture the effect of local labor markets, Petrulis used wage rates, population levels, unem-

\footnotetext{
*Rutgers University, New Brunswick, N.J. New Jersey Agricultural Experiment Station Paper D-02214-3-82. The authors wish to acknowledge the helpful suggestions of Richard M. Stammer.
}

ployment rates, and industry employment. In his analysis, there was partial support of the hypothesis that local labor market conditions influenced firm location decisions. Goode (1978) suggests that unemployment rates for counties are not good measures of local labor availability for several reasons: (1) counties often do not coincide with the notion of a labor shed, and (2) the measurement issues involved can lead to misleading interpretations. In essence, an effective measure of local labor market conditions ought to reflect the price of labor, the quantity and quality, and some measure of work attitudes.

When examining local labor markets in rural communities, an incorporation of spatial elements is critical since location of economic activity (job site) and location of labor source (residence site) diverge to a greater extent than in urbanized areas because of lower densities of population and jobs. However, as reported by Bowles and Beale (1980), non-metropolitan "residents remain overwhelmingly independent of metro labor markets." Thus, a model of rural labor market activity ought to capture the elements of labor availability within rural communities recognizing that the labor market within the rural community is influenced by the demand for and supply of labor in surrounding communities (not necessarily near urban centers), and the distances between the community in question and the surrounding communities.

\section{Commuting Costs}

Christaller (1966) provides a way of thinking concerning the conversion of physical distance to economic distance. For goods, the conversion is quite direct-the transportation cost from one point to another, although Christaller's definition of economic distance incorporates other monetary aspects as well. For consumers traveling to points in space where services are 
offered or for the laborer commuting to the work place, distances are not so readily converted to economic values-not only must the direct cost of commuting be considered, but also the opportunity cost of commuting as well as the associated complex array of social and institutional relationships.

However, it is quite straight forward to argue that for an input (labor) to be attracted from place of residence to work place, it must be paid a price sufficient to cover at least the direct commuting costs. These direct costs of commuting probably differ little if any among various types of labor per unit distance traveled. Differences in the direct costs would be reflected in mode of transportation used and carpooling arrangements. However, the opportunity costs of commuting can be expected to vary among various classes of labor. By definition, commuting time becomes the economic value of foregone activities-either market or non-market. Since many jobs have associated with them conventional work times and hours, commuting time reflects the value placed on foregone nonmarket activities. This suggests that the greater the value of time spent on non-market activities, the less time spent in commuting, given that the decision was made to enter the work force.

Developing measures of the value of time in commuting to work places has benefited from theoretical and empirical exchanges by those interested in measuring the cost of time in recreation demand analysis (McConnell and Strand 1981, Ward 1983, Johnson 1983 and McConnell and Strand 1983). Essentially, the argument is made that "the opportunity cost of time is a crucial element in an individual's allocation of time and that it should vary across individuals" (McConnell and Strand 1983). Income is an element in measuring this opportunity cost, but other personal, social and institutional characteristics influence this cost as well.

In this study, an empirical approach is used to address the question, how and in what manner does the effect of distance to employment opportunities (measured in minutes of travel time) influence the decision to actually participate in the labor force. While no empirical evidence of the opportunity cost of commuting is forthcoming, the study implies a belief that the opportunity cost varies among individuals, and this variation can be captured by occupational classification.

\section{Geographic Access to Employment Opportunities}

The procedure developed to measure GAE in this study for specific communities ${ }^{1}$ has two basic components. The first is the notion of employment opportunities at alternative locations and the second is a measure of distance between communities of residence and communities of employment. Obviously, some participants in the labor force are employed in their community of residence.

In this study, the GAE measure was developed, and the various measures were taken from expressed commuting behavior of existing participants in the labor force. The procedure is not without criticisms. In effect, it describes the commuting patterns of existing job holders, but it limits the potential participants in the labor force to the commuting patterns of existing job holders. A second criticism, embodied in the first, is more severe. That is, there is no theoretical foundation for the exercise. As in the gravity model, commuter flows are influenced positively by the mass at the points of origin and destination and negatively by the simple reciprocal of physical distance. That is, a behavioral model of potential commuters is lacking, including their reaction to different circumstances at the points of the work trip destinations. However, it has been shown that when analyzing the availability of labor in the community of residence, that as distance from that community increases, a given demand for labor in distant communities will result in different labor participation rates in the community of residence (Beck and Jansma 1982, Beck and Goode 1981).

The formula used in this study was of the following form:

$$
\mathrm{GAE}_{\mathrm{i}}=\frac{\sum \mathrm{W}_{\mathrm{ij}} / \mathrm{E}_{\mathrm{i}}}{\mathrm{D}_{\mathrm{ij}}}
$$

where

$\mathrm{GAE}_{\mathrm{i}}$ is the geographic access to employment experienced by residents of community $i$,

$W_{i j}$ is the number of residents of place $i$ who are employed in place $j$, including places where $i=j$,

$\mathrm{E}_{\mathrm{i}}$ is the employable labor force residing in place $\mathrm{i}$, 
$D_{i j} \quad$ is the measured distance between all pairs of places of residence and employment, including $\mathrm{i}=\mathbf{j}$.

Several measures of the distance measure have been used: (1) straight line distance in miles between centroids of the community (Fink 1976), (2) an estimated time in minutes value based on reported commuting time and distance in miles between community centroid pairs (Beck and Jansma, 1982), and (3) average time traveled between community of residence and community of employment, (Hoffman 1981). This study uses the third form. Andrews (1978) differentiates between journey to work trips which he terms local commutes and longer trips. Andrews terms this threshold the "critical isochrone." In this study, the authors hypothesize that an individual is presumed to be indifferent in terms of foregone consumer utility for a work trip less than the threshold value. This threshold value was set at $15 \mathrm{~min}$ utes in this study based on previous surveys (Beck and Jansma 1982). Beyond that value, it is hypothesized that the foregone utility increases with work trips of increasing lengths, but at a decreasing rate.

\section{Employment Opportunities}

The numerator of the measure, $W_{i j} E_{i}$, was developed to provide a proxy for the spatial distribution of employment opportunities. In this study, existing job holders provided this measure of the spatial distribution of job opportunities. This measure was developed by tabulating all work trip destinations and summing across those communities. Thus, the number of job opportunities in community $j$ was given by $\Sigma W_{\mathrm{ij}}$. However, since this measure provided an absolute numerical value for employment opportunities across the communities, and conceptually, a measure of the relative distribution of employment opportunities was more appropriate, this summed value of the $W_{i j}$ was divided by the number of job seekers in community $i\left(E_{i}\right)$. A second delineation was made. Since not all job seekers and jobs are homogeneous, jobs and job seekers were delineated on the basis of occupation. In this study, there are only two broadly defined occupational categories, professionally oriented occupations and non-professionally oriented occupations. ${ }^{2}$ So, the trip distributions were classified on the basis of these occupations resulting in two measures of $\mathrm{W}_{\mathrm{ij}} / \mathrm{E}_{\mathrm{i}}$.
TABLE 1.

Distribution of Occupations of Employed Respondents and Classification.

\begin{tabular}{|c|c|c|c|}
\hline $\begin{array}{l}\text { Occupational } \\
\text { Category }\end{array}$ & Number & Percent & Classification $^{a}$ \\
\hline $\begin{array}{l}\text { Nurses and Health } \\
\text { Workers }\end{array}$ & 45 & 6.8 & $\mathbf{P}$ \\
\hline Teachers & 60 & 9.0 & $\mathbf{P}$ \\
\hline $\begin{array}{l}\text { Technicians and Other } \\
\text { Professionals }\end{array}$ & 60 & 9.0 & $\mathbf{P}$ \\
\hline $\begin{array}{ll}\text { Managers } & \text { and } \\
\text { Administrators } & \end{array}$ & 56 & 8.4 & $\mathbf{P}$ \\
\hline Self Employed & 7 & 1.1 & $\mathbf{P}$ \\
\hline Sales Workers & 48 & 7.2 & $\mathbf{N}$ \\
\hline $\begin{array}{l}\text { Clerical and Kindred } \\
\text { Workers }\end{array}$ & 249 & 37.4 & $\mathbf{N}$ \\
\hline $\begin{array}{l}\text { Craftsmen, Opera- } \\
\text { tives, and Laborers }\end{array}$ & 57 & 8.6 & $\mathrm{~N}$ \\
\hline Service Workers & 82 & 12.3 & $\mathbf{N}$ \\
\hline Armed Services & 1 & 0.2 & $\mathbf{N}$ \\
\hline Total & 665 & 100.0 & \\
\hline
\end{tabular}

"A "P" signifies that women in that occupation were classified as being in a professional occupation, and those with an " $N$ " were classifed as being in a nonprofessional occupation, for purposes of this study.

The rationale for defining the work trip observations into occupational categories is really twofold: (1) it is hypothesized that the factors explaining the economic space in which an account executive offers services are quite different than for a machine operator, and (2) it is hypothesized that the opportunity cost of commuting does vary among labor force participants and that occupation can partially capture this effect.

\section{Data}

Data were collected via a telephone survey conducted by the Eagleton Institute of Politics in March 1980. A random respondent selection procedure was used to ensure that all appropriate age groups were represented and to elicit responses from the communities ${ }^{3}$ delineated for the study. The original target population was to be women between the ages of 16 and 65 , since this age group were thought to be the potential labor force participants. After a pilot survey had been completed, it was found that many women in the 60 to 65 age group had either left the labor force or did not consider themselves potential candidates for the labor market. As a result of the pilot study, it was decided to set the target population to those women 16 to 60 years of age. The sample consisted of 1,183 women residing in Burlington County, New Jersey during the time of the survey, March 1980. 
Of the 1,183 women, 452 were employed fulltime (38.2 percent), 213 were employed parttime (18 percent), and 518 (43.8 percent) were not holding a job at the time of the survey. For purposes of this study, full-time employment was defined as 35 hours a week or more while part-time was defined as being in the labor force, but less than 35 hours per week. The combined full and part-time percentage employed is higher than the $\mathbf{5 1 . 0}$ participation rate for New Jersey females in 1981. (Statistical Abstract of the United States)

Table 1 provides an occupational distribution of the 665 respondents employed either full- or part-time, and the classification system used in this study for the two types of labor.

\section{Analysis}

A regression equation of the following general form was used to estimate the effect of the geographic access to employment variable on actual participation in the labor force.

$$
\mathrm{ALP}=\mathrm{C}_{0} \mathrm{PLP}^{\alpha} \mathrm{GAE}^{\beta}
$$

where

$$
\begin{aligned}
& \mathrm{ALP}=\text { the percent of women residing } \\
& \mathrm{C}_{\mathrm{o}}=\text { a multiplicative constant }
\end{aligned}
$$

Although this model was hypothesized to reveal a nonlinear relationship between the independent and dependent variables, a double-log transformation produced a model which was a linear function of the parameters. ${ }^{4}$

The respective models with their parameter estimates are as follows:
1. Professionally oriented occupations

$$
\begin{aligned}
& \mathrm{ALP}=0.060+0.6171 \mathrm{nGAE}+0.9951 \mathrm{n} \\
& \text { PLP } \\
& \text { (1.18) (9.84) } \\
& \mathbf{R}^{2}=.85 \\
& F=411 \quad \text { t-statistics in parentheses } \\
& \mathrm{DW}=1.99
\end{aligned}
$$

2. Non-professionally oriented occupations

$$
\begin{aligned}
& \mathrm{ALP}=0.076+0.8391 \mathrm{n} \mathrm{GAE}+0.959 \\
& \text { 1n PLP } \\
& \text { (2.17) (10.5) } \\
& \mathrm{R}^{2}=.90 \\
& F=220 \quad t \text {-statistics in parentheses } \\
& \mathrm{DW}=1.79
\end{aligned}
$$

From these equations, an explanation is that GAE is an important explanatory variable of actual participation in the labor force for both occupational groups. However, the parameter estimate is larger for the non-professionally oriented groups, suggesting that women in these occupations are somewhat more sensitive to the location of alternative employment opportunities. This is essentially what one would have expected-that those women with occupations requiring greater levels of education and more career attachment are less sensitive to the location of those job opportunities.

These results suggest that for Burlington County, New Jersey women, responding to a survey question which elicits a positive response to being an actual or potential labor force participant (those holding a job plus those who would accept a job if available) does not necessarily translate into actual job holding. In other words, a variable which essentially contributes toward a relative measure of attracting forces of job opportunities in other communities has a positive influence on the percentage of women actually employed in the community of residence. Thus, for both occupational groupings, as argued above, there is clearly a spatial element involved in developing a measure of labor force activity in rural communities. This spatial element, captured in the access to employment opportunities varia- 
ble, contributes toward a better understanding of rural labor force activity and the forces involved in the decision whether or not to participate in the labor force.

\section{Conclusion}

In a policy sense, what is probably more revealing from this analysis is that the existence of job opportunities within a reasonable commute of places of residence contributes toward a greater proportion of women actually being participants in the labor force. Within our current macroeconomic malaise and uncertainty about energy prices, it does suggest that policy makers, community planners, and firms themselves ought to consider the location of economic activity and its proximity to the labor force they are attempting to attract. This finding suggests that everything else being equal, women prefer to be employed close to their place of residence, and that the economic space women are willing to offer labor services does vary according to their existing occupations.

\section{FOOTNOTES}

'In this study, the term community is used to delineate the geographic units of analysis. They are often synonymous with Census designated Minor Civil Divisions, but in some cases, two or more MCD's were combined to build a geographic unit of analysis.

${ }^{2}$ Occupations assigned to the professional category included all professional, technical, and kindred workers plus managers and administrators. The remaining classifications were such occupations as sales workers, clerical and service workers, and machine operatives.

${ }^{3}$ The geographic units of analysis for this study consisted of 27 combinations of boroughs, townships, and cities of Burlington County, New Jersey. This county was chosen because it is an economically diversified area with a representation of urban, suburban and rural communities.

${ }^{4}$ When the equations were estimated for the effects of GAE and PLP and ALP, the independent variables were weighted by a natural log transformation, and estimated using OLS.

\section{REFERENCES}

Andrews, Howard F., "Journey to Work Considerations in the Labor Force Participation of Married Women," Regional Studies, Volume 12, 1978, 11-20.
Beale, Calvin L., "A Further Look at Non-metropolitan Population Growth Since 1970," American Journal of Agricultural Economics, December, 1976.

Beck, Roger and Frank M. Goode, "The Availability of Labor in Rural Communities," in New Approaches to Economic Development Research in Rural Areas, Northeast Regional Center for Rural Development, Publication 30, July, 1981.

Beck, Roger J. and J. Dean Jansma, "Spatial and Socioeconomic Factors Influencing Labor Force Participation Rates," Journal of the Northeastern Agricultural Economics Council, Fall, 1982.

Bowles, Gladys K. and Calvin L. Beale, "Commuting and Migration Status in Nonmetro Areas," Agricultural Economics Research, July, 1980.

Brown, David L., "Spatial Aspects of Post-1970 Work Force Migration in the United States," Growth and Change, January, 1981.

Christaller, W., Central Places in Southern Germany, Prentice-Hall, Englewood Cliffs, New Jersey, 1966.

Fink, James C., Jr., "An Economic Model for Estimating Work Trip Distributions Between Minor Civil Divisions in Rural Areas," Unpublished Doctor of Philosophy Thesis, The Pennsylvania University, University Park, Pennsylvania, 1976.

Goode, Frank M., "Discussant, Viability of Rural Communities," American Journal of Agricultural Economics, December, 1978.

Hoffman, Colette M., "The Effects of Geographic Access to Employment Opportunities and Socio-Economic Factors on Labor Force Participation: An Econometric Analysis," Unpublished Master of Science Thesis, Rutgers, The State University of New Jersey, New Brunswick, New Jersey, 1981.

Johnson, Thomas G., "Measuring the Cost of Time in Recreation Demand Analysis: Comment," American Journal of Agricultural Economics, February, 1983.

McConnel, Kenneth E. and Ivar Strand, "Measuring the Cost of Time in Recreation Demand Analysis: An Application to Sportsfishing," American Journal of Agricultural Economics, February, 1981.

McConnell, Kenneth E. and Ivar Strand, "Measuring the Cost of Time in Recreation Demand Analysis: Reply," American Journal of Agricultural Economics, February, 1983.

Petrulis, M. F., Firm Locational Decisions: A Qualitative Choice Analysis, ERS Staff Report No. AG ES820928, EDD, USDA, January, 1983.

U.S. Bureau of the Census, Statistical Abstract of the United States: 1982-1983 (103d edition), Washington, D.C., 1982.

Ward, Frank A., "Measuring the Cost of Time in Recreation Demand Analysis: Comment," American Journal of Agricultural Economics, February, 1983.

Wardwell, John M. and David L. Brown, "Population Redistribution in the United States during the 1970's," in New Directions in Urban-Rural Migration, Academic Press, New York, 1980. 